\title{
Pelaksanaan Kegiatan iTalk (Innovation Talk) Untuk Pengembangan Pemikiran Kritis Pada Anak Usia Dini Melalui Budaya Literasi Membaca
}

\author{
Essy Marischa Nadia ${ }^{1 *}$ dan Christye Dato Pango ${ }^{2}$ \\ 1,2 Universitas Ciputra Surabaya \\ e-mail: essy.marischa@ciputra.ac.id ${ }^{1 *}$ \\ *Penulis Korespondensi: E-mail: essy.marischa@ciputra.ac.id
}

\begin{abstract}
iTalk (Innovation Talk) was held by Ciputra University Surabaya Library as part of supporting Community Service (PKM) which is one of the three pillars of the Tridharma in University. This Community Service aims for the purpose of accreditation in every study program at Ciputra University Surabaya. The library chooses the Psychology study program by using observation, interview, and coordinating methods via zoom where later this community service is recognized as the implementation of community service from the Educational Psychology Scientific group as well as cooperating with Wahana Visi Indonesia as partners in the implementation of Community Service. Reading is fundamental in the first year of elementary school for memory and success in later stages. With a reading literacy culture, we can measure the extent to which these children can not read whether at the beginner level, can read but do not understand, can read and can understand what is read. A reading corner can be made in one corner of the house or school which is a creative place for children to play and learn with various literacy and reading activities. The activities that can be done daily with parents in increasing the interest in reading literacy of the child are reading picture story books, inviting children to count, drawing, and reading fairy tales to children before going to bed. In conclusion, reading books can teach children to think critically while also providing opportunities for children to be actively involved in reading and encouraging children to ask questions and discuss while reading.
\end{abstract}

Keywords: critical thinking, reading literacy culture, iTalk (Innovation Talk), Community Service

\begin{abstract}
Abstrak
Kegiatan iTalk (Innovation Talk) ini diadakan oleh Perpustakaan Universitas Ciputra Surabaya sebagai bagian dari pendukung Pengabdian Kepada Masyarakat (PKM) yang merupakan salah satu dari tiga pilar tridharma dalam perguruan tinggi. Pengabdian Kepada Masyarakat ini bertujuan untuk kepentingan akreditasi di setiap program studi yang ada di Universitas Ciputra Surabaya. Perpustakaan memilih program studi Psikologi dengan menggunakan metode observasi, wawancara, serta berkoordinasi melalui zoom dimana nantinya pengabdian kepada masyarakat ini diakui sebagai pelaksanaan pengabdian kepada masyarakat dari kelompok Keilmuan Psikologi Pendidikan sekaligus menggandeng serta Wahana Visi Indonesia sebagai mitra dalam pelaksanaan Pengabdian Kepada Masyarakat. Membaca merupakan hal yang mendasar di tahun pertama sekolah dasar untuk daya ingat dan kesuksesan di tahap selanjutnya. Dengan budaya literasi membaca kita dapat melakukan pengukuran bahwa sejauh mana anak-anak ini tidak bisa membaca apakah ditingkat pemula, bisa membaca tetapi tidak memahami, bisa membaca dan bisa memahami yang dibaca. Pojok baca dapat dibuat di salah satu sudut rumah maupun sekolah dimana merupakan tempat kreatif untuk anak-anak bermain dan belajar dengan berbagai macam kegiatan literasi dan juga membaca. Adapun aktivitas yang dapat dilakukan sehari-hari bersama dengan orang tua dalam meningkatkan minat literasi membaca sang anak yaitu membacakan buku cerita bergambar, mengajak anak berhitung, menggambar, dan membacakan dongeng untuk anak sebelum tidur. Kesimpulannya dengan membaca buku dapat mengajarkan anak-anak untuk berpikir kritis selain itu juga memberikan kesempatan kepada anak-anak untuk secara aktif terlibat dalam bacaan serta mendorong anak-anak untuk bertanya dan berdiskusi selama membaca.
\end{abstract}


Kata kunci: berpikir kritis, budaya literasi membaca, iTalk (Innovation Talk), Pengabdian Kepada Masyarakat

\section{PENDAHULUAN}

Perkembangan informasi saat ini ditandai dengan terjadinya perubahan yang sangat cepat terlebih perubahan dalam bidang kehidupan masyarakat terutama sejak adanya pandemi Covid-19. Dalam hal ini, perpustakaan harus cepat tanggap serta beradaptasi dengan adanya perubahan tersebut. Menurut (Rusmana \& Kuswarno, 2018) bahwa kualitas informasi sangat dipengaruhi oleh tiga hal pokok yaitu relevansi, akurasi dan ketepatan waktu.

Severe Acute Respiratory Syndrome Coronavirus2 (SARS-CoV-2) atau yang dikenal dengan sebutan virus corona atau Covid-19 membuat para tenaga pendidik di Universitas Ciputra Surabaya kesulitan untuk mengadakan Pengabdian Kepada Masyarakat (PKM). Pengabdian kepada masyarakat merupakan bagian integral tri dharma perguruan tinggi yang dalam pelaksanaannya tidak terlepas dari dua dharma yang lain disamping dharma pendidikan dan pengajaran serta dharma penelitian sekaligus melibatkan segenap sivitas akademik seperti tenaga pendidik, tenaga kependidikan, mahasiswa serta alumni.

Oleh karena itu, Perpustakaan Universitas Ciputra Surabaya memberikan kegiatan yang dikemas dalam bentuk iTalk (Innovation Talk) melalui media elektronik (zoom). Kegiatan ini bekerjasama dengan tenaga pendidik dari program studi di Universitas Ciputra Surabaya dimana sebagai pendukung Pengabdian Kepada Masyarakat (PKM) yang merupakan salah satu dari tiga pilar tridharma dalam perguruan tinggi yang wajib dilakukan. Kegiatan iTalk (Innovation Talk) diadakan sekali di setiap bulannya. Kegiatan ini dilakukan dengan adanya permintaan dari rekan-rekan tenaga pendidik yang kesulitan untuk melakukan Pengabdian Kepada Masyarakat ditengah situasi pandemi covid-19.

Disini perpustakaan melakukan observasi dengan bertanya sekaligus mengajak para tenaga pendidik untuk berkerjasama menjadi nara sumber pada kegiatan iTalk (Innovation Talk). Gayung bersambut ajakan perpustakaan diterima oleh program studi Psikologi yang sedang mencari Pengabdian Kepada Masyarakat (PKM) sebagai bagian dari Kelompok Keilmuan Psikologi Pendidikan.

Kegiatan iTalk (Innovation Talk) tersebut bertujuan untuk memberikan informasi baik tips dan trik seputar topik-topik yang sedang trend saat ini khususnya kepada mahasiswa, tenaga kependidikan dan tenaga pendidik di Universitas Ciputra Surabaya maupun masyarakat pada umumnya. Selain itu, dengan adanya kerjasama ini akan mendapatkan beberapa keuntungan antara lain 1) dapat bekerjasama dengan mitra; 2) dapat memberikan pelayanan terhadap masyarakat; 3) adanya hubungan pertukaran yang saling menguntungkan (informasi/ilmu pengetahuan); dan 4) dengan adanya jejaring kerjasama, personal branding akan semakin kuat (Haryanto, 2017).

\section{METODE PELAKSANAAN}

Kegiatan iTalk (Innovation Talk) diawali dengan melakukan koordinasi seperti observasi dan wawancara melalui media zoom ke tenaga pendidik program studi di Universitas Ciputra Surabaya. Observasi dan wawancara tersebut dilakukan ke program studi Psikologi dimana salah satu tenaga pendidik sekaligus dekan Psikologi yaitu Ibu Livia Yuliawati, S.Psi., M.A., Ph.D. yang berkeinginan untuk melakukan kerjasama dengan perpustakaan sebagai pelaksanaan Pengabdian Kepada Masyarakat dari Kelompok Keilmuan Psikologi Pendidikan. Mulai tanggal 14 September - 13 November 2020 dilakukannya koordinasi sampai dengan evaluasi serta pelaporan kegiatan dimana menggandeng serta Wahana Visi Indonesia sebagai mitra dalam pelaksanaan Pengabdian Kepada Masyarakat (PKM). 
Tabel 1. Jadwal Pelaksanaan Kegiatan iTalk (Innovation Talk)

\begin{tabular}{|c|c|c|}
\hline Tanggal & Kegiatan & Koordinasi \\
\hline 17 September 2020 & $\begin{array}{l}\text { Permintaan menjadi narasumber } \\
\text { melalui media sosial (whatsapp) }\end{array}$ & Bu Meilani dan Pak Christye \\
\hline 21 September 2020 & $\begin{array}{l}\text { Diskusi mengenai topik italk } \\
\text { melalui via Zoom }\end{array}$ & $\begin{array}{l}\text { Bu Meilani, Bu Livia dan Pak } \\
\text { Christye, Pak Abi dan } \\
\text { Wahana Visi Indonesia }\end{array}$ \\
\hline 28 September 2020 & $\begin{array}{l}\text { Informasi buku terkait digital } \\
\text { literasi }\end{array}$ & Bu Meilani dan Pak Christye \\
\hline $\begin{array}{l}30 \text { September - } \\
1 \text { Oktober } 2020\end{array}$ & $\begin{array}{l}\text { Konfirmasi materi yang akan } \\
\text { disampaikan }\end{array}$ & Bu Meilani dan Pak Christye \\
\hline 19 Oktober 2020 & $\begin{array}{l}\text { Diskusi Pembagian materi antara } \\
\text { program studi Psikologi dan } \\
\text { Wahana Visi Indonesia }\end{array}$ & $\begin{array}{l}\text { Bu Meilani, Bu Livia dan Pak } \\
\text { Christye, Pak Abi dan Bu } \\
\text { Melliana }\end{array}$ \\
\hline 30 Oktober 2020 & $\begin{array}{l}\text { Permohonan } \\
\text { narasumber }\end{array}$ & $\begin{array}{l}\text { Bu Meilani, Bu Melliana dan } \\
\text { Pak Christye }\end{array}$ \\
\hline 31 Oktober 2021 & $\begin{array}{l}\text { Pelaksanaan iTalk (Innovation Talk) } \\
\text { "Developing Critical Thinking in Kids } \\
\text { Through Literacy" }\end{array}$ & $\begin{array}{l}\text { Bu Meilani, Bu Melliana, Pak } \\
\begin{array}{ll}\text { Christye dan } & \text { tim } \\
\text { perpustakaan } & \end{array}\end{array}$ \\
\hline 04 November 2020 & $\begin{array}{lrr}\text { Permintaan } & \text { kelengkapan berkas } \\
\text { (absensi } & \text { peserta, } & \text { surat } \\
\text { permohonan } & & \text { narasumber, } \\
\text { e-sertifikat, } & \text { surat pernyataan } \\
\text { kerjasama) } & & \end{array}$ & $\begin{array}{l}\text { Bu Meilani, Bu Livia dan Pak } \\
\text { Christye, dan Bu Essy }\end{array}$ \\
\hline 13 November 2020 & $\begin{array}{l}\text { Proposal pelaporan kegiatan iTalk } \\
\text { (Innovation Talk) }\end{array}$ & Bu Meilani dan Pak Christye \\
\hline 08 Desember 2020 & Penyerahan tanda kasih & $\begin{array}{l}\text { Bu Meilani, Bu Livia dan Pak } \\
\text { Christye }\end{array}$ \\
\hline
\end{tabular}

(Sumber : data WhatsApp dan email pustakawan Universitas Ciputra Surabaya)

Atas permintaan adanya Pengabdian Kepada Masyarakat, kegiatan iTalk (Innovation Talk) "Developing Critical Thinking in Kids Through Literacy" ini dilaksanakan di Perpustakaan Universitas Ciputra secara daring/online melalui Zoom. Kegiatan ini dimulai pada pukul 09.00 - 11.00 WIB yang diikuti 40 orang peserta baik orang tua, mahasiswa, alumni, tenaga kependidikan maupun tenaga pendidik dengan dua nara sumber yaitu yang pertama Ibu Melliana Layuk sebagai Spesialis Pendidikan Wahana Visi Indonesia (WVI) zonal Jawa, Kalimantan Barat, dan Sumatera serta nara sumber kedua ibu Meilani Sandjaja sebagai tenaga pendidik dari program studi Psikologi Universitas Ciputra Surabaya sekaligus yang dibantu oleh Pak Christye Dato Pango sebagai moderator dan Pustakawan Universitas Ciputra Surabaya. Para nara sumber menyampaikan materi sesuai dengan keahlian masing-masing dimana materi yang disampaikan melalui media power point. Acara ini diharapkan dapat memperoleh pengetahuan yang mampu dipraktekkan oleh 
tenaga pendidik dan orang tua yang sedang menghadapi hambatan dalam mendalami daya kritis anak melalui budaya literasi khususnya dalam hal membaca.

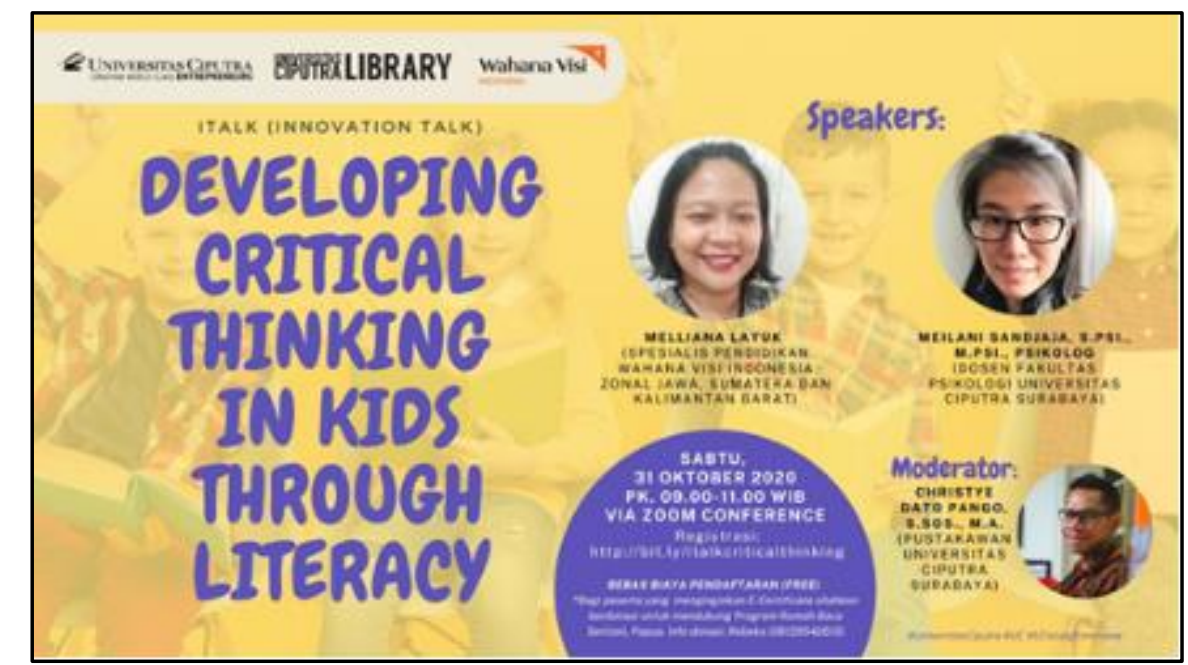

Gambar 1. Poster iTalk "Developing Critical Thinking in Kids Through Literacy" (Sumber : https://www.uc.ac.id/library)

\section{HASIL dan PEMBAHASAN}

Penjelasan dari nara sumber di sesi pertama, Ibu Meiliana Layuk yang menjelaskan bahwa Yayasan Wahana Visi Indonesia (WVI) merupakan yayasan sosial kemanusiaan Kristen dimana sejak tahun 1998 telah menjalankan program pengembangan masyarakat yang berfokus pada masyarakat kelas bawah terutama anak-anak tanpa membedakan gender, etnis, ras, dan agama untuk membuat peralihan yang berkesinambungan dalam kehidupan mereka.

Menurut penjelasan Ibu Meiliana Layuk, sejak tahun 2012 Wahana Visi Indonesia (WVI) bersama rekanan International World Vision telah menguji coba menggunakan metode baru melalui proyek pendidikan di 25 negara dengan fokus pada membangun pembelajaran dan ketrampilan dasar dalam hal membaca. Membentuk rekanan yang strategis dengan Save the Children, Wahana Visi Indonesia (WVI) juga mengambil model peningkatan transliterasi baru dimana salah satu project modelnya yaitu wahana literasi yang diterapkan khususnya di daerah dampingan seperti wilayah Papua, Sentani, Biak Numfor, Lanny Jaya, Manggarai Timur, Manggarai Barat, dan Landak terkait dengan adanya peningkatan literasi membaca. Seperti yang kita ketahui bahwa membaca di tahun pertama sekolah dasar adalah sangat penting untuk daya ingat dan kesuksesan di kelas berikutnya. Anak-anak yang tidak mengembangkan ketrampilan membaca selama awal pendidikan dasar akan berada pada lintasan kemajuan pendidikan yang terbatas seumur hidup dengan peluang ekonomi yang juga terbatas. Budaya literasi membaca inilah yang membuka potensi manusia serta landasan pembangunan yang mengarah pada kesehatan dan peluang kerja yang lebih baik serta masyarakat yang mebih aman dan stabil.

Ada tiga intervensi pada wahana literasi, yaitu pelatihan guru, pendampingan aksi masyarakat/komunitas bahwa literasi sangat diperlukan serta kreasi material pendukung literasi yang ada disekitarnya Sebelum melakukan ketiga intervensi tersebut dilakukan pengukuran kepada anak-anak sejauh mana anak-anak ini tidak bisa membaca apakah ditingkat pemula, bisa membaca tapi tidak memahami, bisa membaca dan bisa memahami yang dibaca. Pada pelatihan guru, Wahana Visi Indonesia (WVI) mendampingi guru-guru dalam beberapap sesi seperti pengantar pengembangan membaca anak, penilaian formatif, 
permasalahan bahasa dalam literasi, kesadaran huruf, kesadaran fonemik, kelancaran membaca, kosakata, dan pemahaman membaca. Aksi komunitas Wahana Visi Indonesia (WVI) antara lain (1) aktivitas membaca masyarakat seperti melaksanakan kemah/rumah baca, baca maraton, sobat baca, dan waktu cerita; (2) lokakarya ketrampilan membaca seperti perkembangan literasi dan bahasa anak, kegiatan harian untuk kesiapan membaca, membaca bersama dan untuk anak, membuat materi untuk membantu anak membaca dan pojok baca serta (3) pengembangan lingkungan literasi seperti perpustakaan mini untuk anak-anak, teknik mengisi bank buku dan cara menjilid buku. Menurut Ibu Meiliana Layuk bahwa" memperdengarkan kisah-kisah menarik kepada anak-anak akan sangat mendukung perkembangan emosional, sosial, moral dan intelektual mereka" ". Hal ini dapat dilakukan dengan membacakan dongeng kepada anak usia dini untuk menstimulus daya imajinatif \& kreatif pada anak (Hudhana \& Ariyana, 2018).

Dengan adanya kreasi material pendukung literasi dapat dibuat Pojok Baca dimana merupakan tempat kreatif untuk anak-anak bermain dan berlatih dengan berbagai macam aktivitas literasi dan membaca. Di pojok baca ini dapat disiapkan berbagai macam buku, permainan yang berhubungan dengan literasi seperti balok dengan cetakan huruf, kartu bergambar, permainan huruf dan lain-lain. Material yang disediakan harus tersedia setiap harinya dan area untuk membaca maupun bermain harus dijaga agar tetap bersih dan senyaman mungkin. Pojok baca merupakan sumber daya bagi sobat baca, orang tua atau siapapun yang berkunjung sekaligus mendampingi anak-anak untuk membaca dan bersenang-senang sambil belajar. Variasi buku yang tersedia boleh berasal dari berbagai subjek yang sesuai dengan karakter atau minat anak. Hal ini dimaksudkan untuk memicu daya tarik anak untuk membaca buku. Untuk mengantisipasi rasa bosan pada koleksi yang tersedia, koleksi buku dapat di-rolling dengan koleksi pojok baca dari tempat lain apabila terdapat beberapa pojok baca (Hidayatulloh et al., 2019).

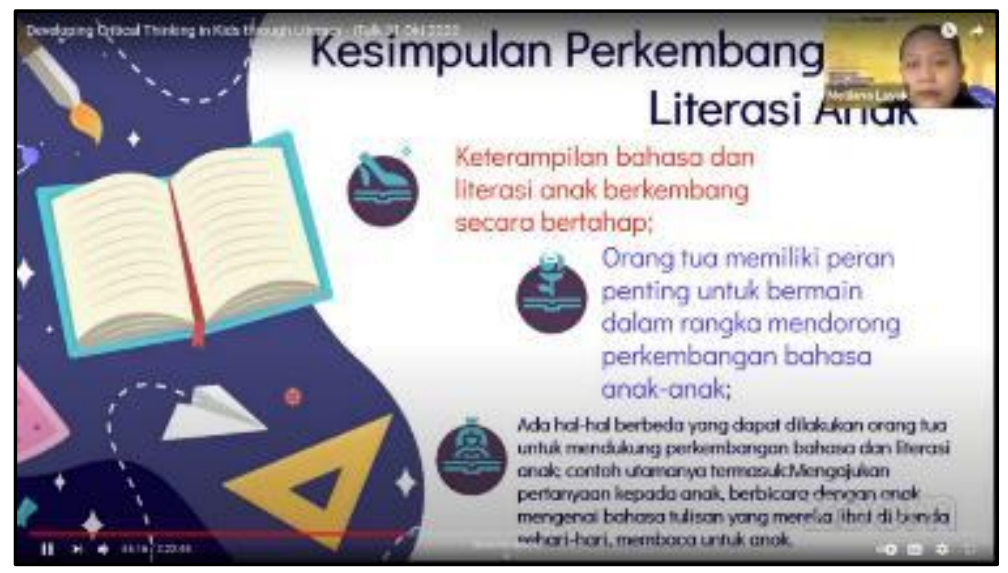

Gambar 2. Materi Ibu Meiliana Layuk

(Sumber : https://www.uc.ac.id/library)

Pemaparan materi selanjutnya dari nara sumber kedua yaitu Ibu Meilani Sandjaja selaku tenaga pendidik dari program studi Psikologi Universitas Ciputra Surabaya. Pemaparan ini terdapat dua topik bahasan yaitu literatur bacaan serta cara berpikir kritis dan buku bacaan yang sesuai untuk anak tingkat sekolah dasar.

Menurut Ibu Meilani Sandjaja, literasi membaca menjadikan aktivitas yang sangat erat karena menerangkan berbagai macam aspek yang membutuhkan minat, motivasi dan atensi dalam diri agar dapat mempertahankan dan menyenangi aktivitas membaca. Dalam hal memilih dan mencari bacaan untuk anak-anak, yang harus diperhatikan adalah kualitas 
dan isi bacaan, kerumitan konseptual atau alur bacaan, keterbacaan bahasa atau besar kecilnya huruf, serta cara pelafalan dari isi bacaan tersebut. Buku bacaan yang sesuai dengan karakter anak adalah buku bacaan yang mempunyai bahasa dan alur cerita yang mudah dicerna, berisi banyak gambar, menampilkan tokoh/karakter yang disukai anakanak dalam cerita serta buku yang mempunyai cerita dimana dapat mengajak anak ke tempat atau waktu lain di dalam cerita tersebut. Anak-anak usia sekolah dasar sudah mampu terlibat secara aktif untuk memikirkan dan memecahkan permasalahan yang dihadapi tokoh protagonis atau memprediksikan kelanjutan ceritanya. Bagi anak-anak yang mengalami kesulitan memahami isi bacaan dapat menerapkan metode menjawab pertanyaan mind mapping, yakni dengan menjawab kata tanya apa, siapa, kapan, mengapa, di mana dan bagaimana berdasarkan buku yang baru saja mereka baca (Imani \& Efrina, 2018).

Adapun nilai intrinsik bacaan bagi anak-anak yang dapat dikembangkan menjadi kriteria penilaian ketika orang dewasa dituntut untuk memilih buku yang layak dibaca atau tidak yaitu pertama, sejauh mana buku tersebut memberikan kegembiraan, kesenangan, kepuasan kepada anak-anak; kedua, dapat membimbing dan mengembangkan potensi imajinasi sang anak; dan yang ketiga, buku bacaan harus mampu memberikan pengalaman baru kepada anak-anak (Sudarsana, 2018).

Disekitar kita masih sering ditemukan beberapa anak yang kurang senang membaca. Hal ini dikarenakan adanya berbagai macam faktor antara lain anak tidak memahami apa yang dibaca, membaca itu membosankan, anak tidak suka membaca dengan bersuara nyaring atau didengarkan orang lain, bukunya terlalu tebal dan bukunya terlalu banyak tulisan atau tidak bergambar. Menurut (Sudarsana, 2018) ada beberapa hal yang menyebabkan rendahnya membaca seseorang antara lain : (1) kebiasaan lama seperti menggerakkan bibir untuk melafalkan, menggunakan jari atau benda untuk menunjuk kata yang dibaca, dan menggerakkan kepala ke kanan dan ke kiri, (2) tidak bersemangat dalam memahami arti bacaan, dan (3) persepsi yang kurang sehingga lambat dalam menginterpretasikan apa yang dibaca.

Salah satu peran orang dewasa yaitu guru, orang tua, dan komunitas yang dalam hal ini adalah mengembangkan kecintaan anak-anak pada membaca. Dengan membaca dapat menstimulasi pikiran dan memicu imajinasi sehingga sejak usia dini anak-anak sudah mempunyai potensi untuk berpikir kritis.

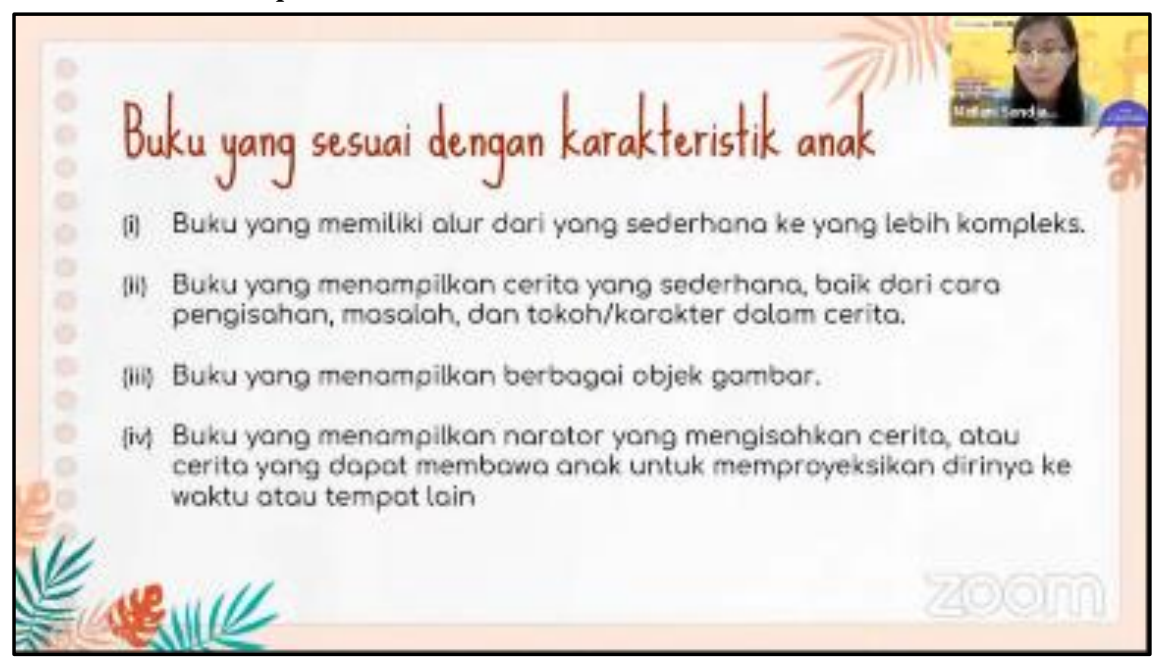

Gambar 3. Materi Ibu Meilani Sandjaja

(Sumber: https://www.uc.ac.id/library) 
Berpikir kritis yaitu suatu proses evaluasi untuk memperoleh pemahaman, keterampilan dan pengetahuan untuk memecahkan masalah dan mengambil keputusan secara deduktif, induktif dan evaluatif sesuai dengan tahapannya. Selain itu, juga menjadikan salah satu kemampuan dalam mendidik anak-anak untuk berani bertanya dan mengekspresikan pengetahuan dan memahami suatu informasi yang diberikan atau disampaikan kepada mereka.

Buku secara efektif dapat mengajarkan anak-anak berpikir secara kritis karena memberikan dorongan kepada anak-anak agar terlibat secara aktif dalam membaca sambil merenungkan pertanyaan, nilai serta ide secara bersamaan. Untuk mendukung anak- anak berpikir secara kritis juga perlu dilakukannya interaksi dengan bertanya dan berdiskusi setelah atau selama membaca buku sehingga dapat menstimulasi aktivitas otak anak. Dengan mendapatkan bacaan yang bervariasi disertai dengan diskusi yang menarik maka anak-anak akan mampu untuk memperkaya informasi dan mengembangkan ketrampilan berpikir kritis. Orang tua dan tenaga pendidik juga dapat mendukung untuk menentukan prediksi, tujuan, mengklarifikasi kata yang sulit serta mengajukan pertanyaan dalam buku yang dibaca oleh anak. Yang tidak kalah terpenting, kita perlu membuat lingkungan yang mendorong anak-anak berpikir secara kritis serta suasana yang menyenangkan sekaligus memberikan dorongan agar mereka dapat bertanya, membuat prediksi dan mengatur ideide yang mendukung penilaian/kesimpulan yang diambil.

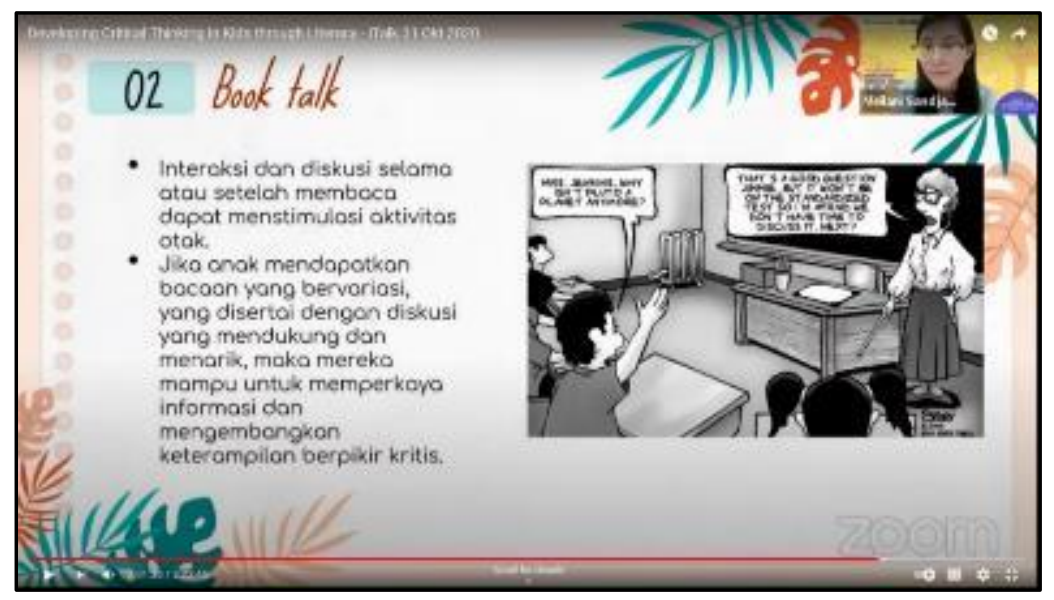

Gambar 4. Materi Ibu Meilani Sandjaja

(Sumber: https://www.uc.ac.id/library)

Antusiasme peserta sangat interaktif dengan mengajukan beberapa pertanyaan seperti salah satunya dari pak Muhammad yang menanyakan tips menghadapi anak yang gampang bosan jika diajak untuk belajar. Pertanyaan ini ditanggapi langsung oleh Ibu Meiliana Layuk, bahwa berdasarkan pengalamannya ketika mendampingi para guru diharapkan dapat mewujudkan suasana yang menggembirakan dan nyaman dengan berbagai macam permainan agar anak-anak tidak bosan dalam belajar. Selain itu, adanya interaksi dengan anak-anak ketika orang tua atau guru membacakan sebuah buku seperti "hal apa sih yang menarik dari kalimat yang kita baca tadi?".

Dari pihak Perpustakaan Universitas Ciputra Surabaya mengucapkan terima kasih kepada dua nara sumber yaitu Ibu Meiliana Layuk sebagai Spesialis Pendidikan Wahana Visi Indonesia Zonal Jawa, Kalimantan Barat, dan Sumatera dan Ibu Meilani Sandjaja, S.Psi., M.Psi., Psikolog sebagai tenaga pendidik program studi Psikologi Universitas Ciputra Surabaya serta Pak Christye Dato Pango sebagai moderator sekaligus Pustakawan di perpustakaan Universitas Ciputra Surabaya pada kegiatan i'Talk (Innovation Talk) 
"Developing Critical Thinking in Kids Through Literacy" dan semua peserta yang sudah hadir via daring/online (zoom) untuk mengikuti kegiatan tersebut, sekaligus semua pihak yang telah ikut membantu dan berpartisipasi baik berupa pikiran, tenaga, maupun sarana prasarana sehingga kegiatan ini berlangsung dengan lancar dan sukses.

\section{KESIMPULAN}

Tidak sulit bagi orang tua dan tenaga pendidik untuk ikut serta dalam mendampingi anak-anak membentuk dalam dirinya betapa pentingnya budaya literasi membaca serta berpikir secara kritis. Orang tua maupun tenaga pendidik juga dapat memberikan dukungan kepada anak-anak sekaligus menciptakan suasana yang menyenangkan guna mendukung pengembangan diri anak. Dengan membaca buku dapat mengajarkan anakanak untuk berpikir kritis selain itu juga memberikan kesempatan kepada anak-anak untuk secara aktif terlibat dalam bacaan serta mendorong anak-anak untuk bertanya dan berdiskusi selama membaca. Terdapat beberapa aktivitas yang dapat dilakukan untuk menumbuhkan minat budaya literasi membaca pada anak usia dini, salah satunya yaitu dengan menggunakan media pengajaran yang menarik bagi anak usia dini seperti membacakan buku cerita bergambar dimana merangsang anak-anak untuk membaca, mengajak anak berhitung, meminta anak untuk membuat catatan belanjaan, menggambar, membacakan dongeng untuk anak sebelum tidur, dan kegiatan-kegiatan lainnya yang biasa dilakukan orang tua sehari-hari bersama dengan anak-anak.

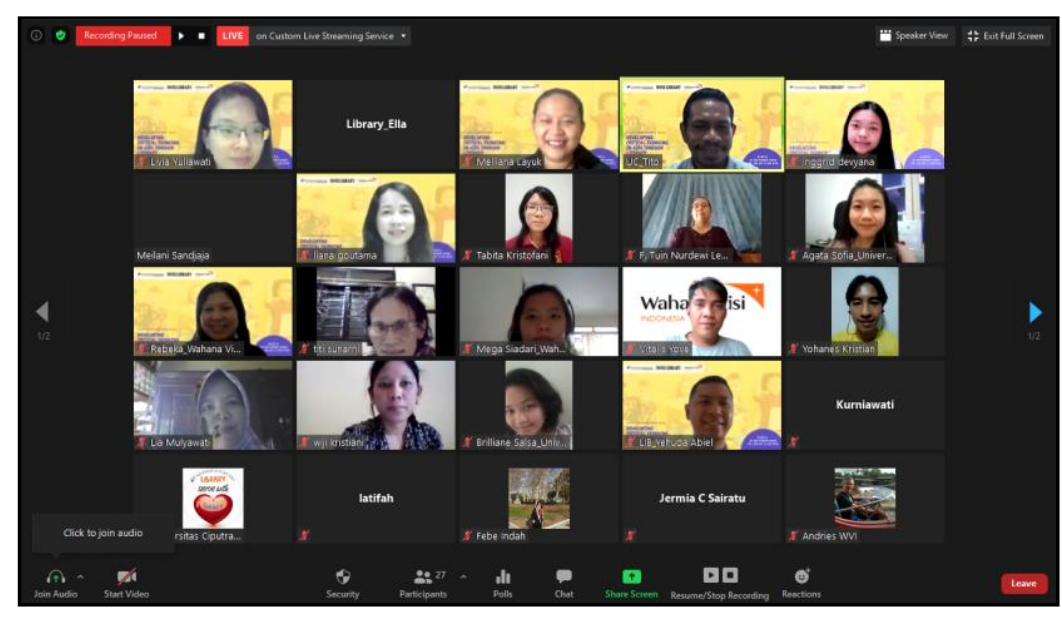

Gambar 5. Foto peserta iTalk

"Developing Critical Thinking in Kids Through Literacy"

(Sumber: https://www.uc.ac.id/library)

\section{UCAPAN TERIMAKASIH}

Penulis mengucapkan terima kasih kepada media masa online www.timesindonesia.co.id yang telah memberikan kesempatan untuk menyebarluaskan pelaksanaan kegiatan i'Talk (Innovation Talk) "Developing Critical Thinking in Kids Through Literacy"yang diadakan oleh Perpustakaan Universitas Ciputra Surabaya yang bekerjasama dengan Wahana Visi Indonesia (WVI) dan program studi Psikologi Universitas Ciputra Surabaya sebagai bagian dari pengabdian kepada masyarakat. Kegiatan tersebut telah dimuat dalam link http://www.timesindonesia.co.id/read/news/308519/perpustakaanuniversitas-ciputra-surabaya-bahas-kemampuan-daya-kritis-anak-melalui-literasi 


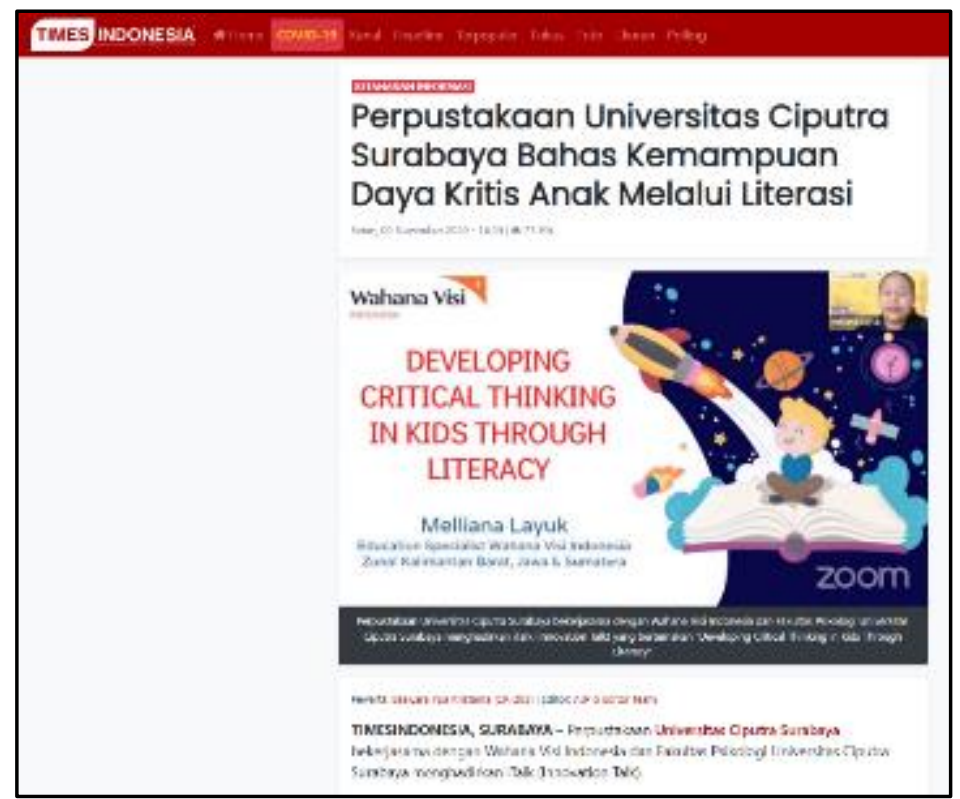

Gambar 6. Publikasi di media masa Times Indonesia (Sumber: https://www.uc.ac.id/library)

\section{DAFTAR PUSTAKA}

Haryanto, J. O. (2017). Beyond Marketing: Growth and Sustainability. KPG (Kepustakaan Populer Gramedia).

Hidayatulloh, P., Solihatul, A., Setyo, E., Fanantya, R. H., Arum, S. M., Istiqomah, R. T. U. N., \& Purwanti, S. N. (2019). Peningkatan Budaya Literasi melalui Kegiatan Pojok Baca di SD Muhammadiyah Plus Malangjiwan Colomadu. Buletin Literasi Budaya Sekolah, 1(1), 611. https://doi.org/10.23917/blbs.v1i1.9301

Hudhana, W. D., \& Ariyana, A. (2018). Menanamkan Budaya Literasi pada Anak Usia Dini Melalui Dongeng. Lingua Rima: Jurnal Pendidikan Bahasa Dan Sastra Indonesia, 7(2), 80-85. https://doi.org/10.31000/lgrm.v7i2.882

Imani, A. N., \& Efrina, E. (2018). Mind Mapping; Cara Efektif Bagi Anak Berkesulitan Belajar dalam Memahami Bacaan. Jurnal Penelitian Pendidikan Khusus, 6(1), 112-117. http://ejournal.unp.ac.id/index.php/jupekhu/article/view/101688

Rusmana, A., \& Kuswarno, E. (2018). Analisis Sistem Informasi. Universitas Terbuka. Sudarsana, U. (2018). Pembinaan Minat Baca. Universitas Terbuka. 